\title{
EARLY REPORTED CASES ON SLANDER OF TITLE
}

\section{Alan Dowling, School of Law, Queen's University Belfast}

Actions in tort today arising as the result of something the defendant has written or spoken are commonplace. Newspapers, broadcasters and private individuals run the risk of actions being taken against them if they publish material defamatory of the plaintiff. Defamation aside, an action in negligence is possible as a result of a statement made by the defendant in circumstances where the various elements of that tort are present. Defamation and negligence are well-known. A less familiar cause of action, "curious in its origin, its history and its present features", ${ }^{1}$ likewise based on words spoken or written by the defendant, also exists, known as slander of title. According to Halsbury, ${ }^{2}$ an action for slander of title lies against anyone who falsely and maliciously disparages the title of an owner of real or personal property, and by doing so causes him special damage. Gatley's formulation of the cause of action does not differ in any material respect. ${ }^{3}$ While the need to show special damage has been removed in cases to which the Defamation Act (NI) 1955 applies, ${ }^{4}$ the essence of the action, as the texts make clear, is that the defendant has made a statement which puts the plaintiff's title to land or personal property into question, in consequence of which the plaintiff has suffered damage. The statement of the cause of action by Clerk and Lindsell is fuller, and refers to a transaction relating to the plaintiff's land which has been lost as a result of the defendant's statement. According to Clerk and Lindsell, an action lies "if property of any kind is for sale, and anyone without lawful excuse comes forward and falsely alleges that any charges or liabilities exist with respect to it, or otherwise calls into question the right or capacity of the vendor to make a good conveyance and in consequence the bargain goes off'. ${ }^{5}$

Slander of title is nowadays treated as part of a wider generic tort of malicious falsehood, which encompasses also slander of goods. ${ }^{6}$ Slander of title is undoubtedly however the origin of this wider tort. The term "slander" suggests a relationship with the tort of defamation, and so there is,

1 British Railway Traffic and Electric Co Ltd v The CRC Co Ltd \& LCC [1922] 2 K.B. 260, per McCardie J.

228 Halsbury's Laws of England (4 ${ }^{\text {th }}$ ed., 1979) para.262.

3 Gatley on Libel and Slander (10 ${ }^{\text {th }}$ ed., 2004) para.20.14.

4 S.3 provides that in an action for slander of title, slander of goods or other malicious falsehood, it is not necessary to allege or prove special damage where the words on which the action is founded are calculated to cause pecuniary damage and are published in writing or other permanent form; or are calculated to cause pecuniary damage to the plaintiff in respect of any office, profession, calling, trade or business carried on by the plaintiff at the time of publication.

5 Clerk and Lindsell on Torts (18 ${ }^{\text {th }}$ ed., 2000) para.23.06.

6 See Gatley para.20.2; Price \& Duodu, Defamation Law, Procedure \& Practice (3 ${ }^{\text {rd }}$ ed., 2004) para.6.01. 
Holdsworth describing the two torts as springing from the same root. ${ }^{7}$ It has been pointed out however that in cases of slander of title it matters not whether the words have been spoken or have been written, and to that extent the word "slander" in the context of actions based on statements regarding the plaintiff's title is misleading. ${ }^{8}$ Further, while actions for defamation and for slander of title may have sprung from a common root, they soon developed separate shoots. It was established at an early date that the limitation period applicable to actions for slander did not apply to actions for slander of title. ${ }^{9}$ Equally, while an action for slander does not survive the death of the person defamed, an action for slander of title may be brought by the personal representatives after the death of the person whose title has been disparaged. ${ }^{10}$ The statement of Tindal C.J. in Malachy v Soper ${ }^{11}$ that "an action for slander of title is not properly an action for words spoken, or for libel written and published, but an action on the case for special damage sustained by reason of the speaking or publication of the slander of the Plaintiff's title" does not mention the common root of the causes of action, but indicates clearly that the root had divided.

The tort of slander of title is of ancient origin. Modern instances concerning title to land are rare, but from late in the sixteenth century up until shortly after the Restoration the courts were kept busy with actions brought by landowners whose complaint was that their ownership of their land had been put in doubt as the result of something said by those against whom the actions were brought. The emergence of the tort coincided with development of the law of defamation, but by the early seventeenth century the differences between actions based on words spoken of the plaintiff's person and actions based on words spoken of the plaintiff's title to his land were emerging. After the Restoration the tort seems to have gone into hibernation for the best part of a century, before re-emerging to provide the courts with business once more. When it did however, the main aspect of the tort with which the courts were concerned, namely the need for the plaintiff to show the defendant had spoken the words complained of out of malice, was one which had featured very little in the early days. It was that feature which both made the burden on the plaintiff more onerous, and which led to the tort being nowadays being classified as an instance of the more general tort of malicious falsehood already mentioned. This article looks at the development of the law in the early reported cases, before this more general tort had been identified. ${ }^{12}$

7 Holdsworth, "Defamation in the sixteenth and seventeenth centuries" (1924) 40 L.Q.R. 302 \& 397 at 402; (1925) 41 L.Q.R. 13; Holdsworth, 8 History of English Law (1925) p.351.

8 Gatley, para.20.2.

9 Law v Harwood (1628) Cro. Car. 140; sub nom Harwood \& Lowe Palm. 529; sub nom Lowe v Harewood Jones W. 196; Nurse v Pounford (1629) Hetley 161. Below, p.257.

10 Hatchard v Mege (1887) 18 Q.B.D. 771. For a comparison between actions for defamation and actions for malicious falsehood, see Price \& Duodu, op. cit., para.6.02.

11 (1836) 3 Bing. (N.C.) 371.

12 For earlier reviews see Kiralfy, The Action on the Case (1951) chap.9; Newark, "Malice in actions on the case for words" (1944) 60 L.Q.R. 366. 


\section{Illustrations}

While modern examples of actions for slander of title to real property are rare, they are not impossible to find. In Lover $\mathrm{v}$ Pearce, ${ }^{13}$ an action for slander of title was successfully brought by a plaintiff who had entered into a contract to assign a lease. The defendants were the personal representatives of the lessor who had been asked to give consent to the assignment, as required under the terms of the lease. The lessor had granted consent, but the consent contained a statement to the effect that in agreeing to the assignment the lessor was not admitting that the lease had been validly granted or was binding on her. The purchaser rescinded the contract and the plaintiff resold at a loss which he sought to recover from the defendants. Buckley J. held that the lessor's statement carried the inference that the lease might be open to attack, and that as the lessor did not believe that she could impugn the lease, the statement was actionable. More recently, in Arthur v Arthur, ${ }^{14}$ an action was brought against a defendant as a result of the defendant's denial that the plaintiff had a right of way, which led to a prospective purchaser breaking off negotiations with the plaintiff. The plaintiff was able to establish that the defendant was wrong in denying a right of way existed, and that he had suffered damage in the loss of the sale, but failed in his action for slander of title because the defendant had not acted with malice. Cornwall Gardens PTE Ltd v RO Garrard \& Co Ltd ${ }^{15}$ is the other side of the coin, where it was the assertion of a right of way which was the basis of an action for slander of title, though the action was found to be out of time. A modern Irish illustration is Malone $\mathrm{v}$ McQuaid, ${ }^{16}$ in which the plaintiff brought an action as a result of the defendant's having registered a judgment mortgage against an equitable interest alleged by the defendant to be owned by the plaintiff's husband in property of which the plaintiff was the registered owner. The court held that no equitable interest existed in the husband, but went on to dismiss the plaintiff's claim for damages as the defendant had not acted out of malice.

Older cases illustrate the variety of statements, and circumstances in which statements are made, that can lead to an action for slander of title. A number of these involve auctions disrupted as a result of statements made at the auctions. A dramatic example is Steward v Young,${ }^{17}$ where the defendant announced at an auction of furniture, "I forbid the sale; for I hold a bill of sale of all the goods in the house in favour of Mr Alexander. I shall not allow a single lot to leave the house." Statements made in other cases have been equally effective in disrupting sales. In Pater $\mathrm{v}$ Baker, ${ }^{18}$ a highways surveyor announced at an auction that he would prevent any purchaser occupying the property in sale until certain roads had been made up. In both Hargreave $\mathrm{v}$ Le Breton, ${ }^{19}$ and Watson $\mathrm{v}$ Reynold ${ }^{20}$ auctions were disrupted as the result of interventions by attorneys acting on behalf of their clients: in

13 (1961) 178 E.G. 333.

$1419^{\text {th }}$ February 1986 , unrep. C.A..

15 [2001] E.W.C.A. Civ. 699.

$1628^{\text {th }}$ May 1998, unrep. High Court, RoI.

17 (1870) L.R. 5 C.P. 122.

18 (1847) 3 C.B. 831

19 (1769) 4 Burr. 2422.

20 (1826) Moo. \& M. 1 
the former, the attorney announced that a previous owner of the land in sale who had mortgaged it to the vendor had been made bankrupt before the mortgage was made; in the latter, that proceedings in Chancery were taking place relating to the property in sale, that there had been a breach of covenant in the lease under which the land in sale was held, and that proceedings would be taken against the purchaser of the property. Announcements at auctions of breaches of covenant affecting the land in sale led also to actions for slander of title in Smith v Spooner ${ }^{21}$ and Brook v Rawl. ${ }^{22}$

Auctions are by no means a pre-requisite however to actions for slander of title. In Pitt v Donovan, ${ }^{23}$ an action was brought as the result of a letter by the defendant to a purchaser of the plaintiff's lands, asserting that the plaintiff's predecessor in title was not of sound mind when he sold the land, and that the plaintiff's title would sooner or later be contested; in Millman v Pratt, ${ }^{24}$ the defendant had published a notice that the vendor was not entitled to sell the land; and in Atkins v Perrin, ${ }^{25}$ an action was brought by the widow of an intestate as a result of publication by the defendant of handbills offering a reward to anyone who could produce a will made by the deceased after the date of his marriage to the plaintiff, and the defendant's announcement at the sale of land that the title to the property was disputed. Perhaps more interesting to conveyancers is Ravenhill $\mathrm{v}$ Upcott, ${ }^{26}$ where the defendant, the proprietor of a newspaper, published an advertisement asking the public not to buy the land offered for sale by the plaintiff "without ascertaining that the title deeds of the same are correct, as the heirs of [a named person] are not dead, or abroad, but are still alive", the implication being that the plaintiff's title was in doubt. In fact the title to the land had already been registered in the name of the plaintiff and was therefore indefeasible.

The plaintiffs' success or failure in these instances need not concern us for the present. One point may however be made at this stage. In many of the instances in which actions were brought for slander of title, the statement upon which the action was based was an assertion by the defendant, or his solicitor, in defence of rights in the land claimed by the defendant. One such instance is Smith v Spooner, where the action was based on the defendant's statement to the auctioneer of a house offered for sale by the plaintiff that it was no use to put the house up for sale, as the house was the defendant's. The statement was based on breaches of covenant in the lease under which the house was held having taken place, and the defendant's right, as lessor, to recover possession in consequence. The complexity of land ownership and the difficulties of proving title to land are well known. If assertions by the defendant of a claim to the land were to be actionable as slander of title, the implications for anyone believing he had a right in or claim to the land were clearly going to be serious. The same would be true for solicitors employed to advise on a claim. Hargrave $\mathrm{v}$ Le Breton and Watson $\mathrm{v}$ Reynolds are both instances where attorneys were the defendants in actions for slander of title.

\footnotetext{
21 (1810) 3 Taunt. 246.

22 (1849) 4 Ex. 521.

23 (1813) 1 M. \& S. 639

24 (1824) 2 B. \& C. 486.

25 (1862) 3 F. \& F. 179.

26 (1869) 20 L.T. 233.
} 
The need to strike a balance between allowing a plaintiff to bring an action where he suffered damage as a result of a statement disparaging the plaintiff's title, and allowing other parties to assert claims to the land themselves or through their advisers, was something the courts would have to address in developing the tort of slander of title.

\section{Origins of the Tort}

In the early development of the law the King's courts afforded little relief to plaintiffs as a result of words spoken. ${ }^{27}$ Local courts entertained actions for defamation, and so did the Ecclesiastical courts, but while a successful action in the local courts could lead to an award of damages, ${ }^{28}$ no such relief was possible in the Ecclesiastical courts. ${ }^{29}$ Nor was any relief at all possible in the King's courts for words spoken of the plaintiff, apart from cases of scandalum magnatum which were limited to the "great men of the realm". ${ }^{30}$ At the beginning of the sixteenth century however both the King's Bench and the Common Pleas began to entertain actions in which the plaintiff's complaint was that the defendant had accused him of theft. This led in turn to cases involving statements alleging the commission of other offences, as to the plaintiff's conduct or competence in his profession, and what have been termed "accusations of socially unfortunate conditions" 31 such as having a venereal disease or being illegitimate.

\section{Bastardy cases}

The early reports contain many examples of cases of plaintiffs bringing action as a result of being called a bastard. Such an accusation alone would afford no relief in the common law courts. What brought the complaint within the jurisdiction of those tribunals was damage sustained by the plaintiff as a result of words spoken of the plaintiff. In Nelson v Staff, ${ }^{32}$ the damage relied on was the loss of the plaintiff's intended marriage. Matthew v Crass, ${ }^{33}$ Sell v Facy, ${ }^{34}$ Harwood $\mathrm{v}$ Hopkins ${ }^{35}$ and Bridge $\mathrm{v}$ Langton $^{36}$ are

27 Holdsworth, 3 History of English Law (1908) p.408 ff; Plunknett, A Concise History of the Common Law (5 $5^{\text {th }}$ ed., 1956) p.484 ff; Potter, Historical Introduction to English Law and its Institutions (4th ed., 1958) p.430 ff; Milsom, Historical Foundations of the Common Law (2 ${ }^{\text {nd }}$ ed., 1981) p.379 ff; Baker, An Introduction to English Legal History $\left(4^{\text {th }}\right.$ ed., 2002) p.436 ff; Fifoot, History and Sources of the Common Law (1949) p.126 ff. For a more detailed treatment see Baker, 6 Oxford History of the Laws of England (2003) ch.44; Baker, 2 The Reports of Sir John Spelman (1978) 94 Selden Society p.236 ff; Helmholz, Select Cases on Defamation to 1600 (1985) 101 Selden Society p.lxvi ff; Holdsworth, "Defamation in the sixteenth and seventeenth centuries" (1924) 40 L.Q.R. 302 \& 397; (1925) 41 L.Q.R. 13; Holdsworth, 5 History of English Law (1924) p.205 ff; Holdsworth, 8 ibid., p.333 ff.

28 Plunknett, A Concise History of the Common Law (5 $5^{\text {th }}$ ed., 1956) p.484. For actions in local courts see also Holdsworth, 2 History of English Law (1903) p. 83.

29 For defamation in the Ecclesiastical courts see Carr, "The English Law of Defamation" (1902) 18 L.Q.R. 270.

30 For scandalum magnatum see Baker, 2 The Reports of Sir John Spelman (1978) 94 Selden Society p.244; Lassiter, "Defamation of Peers: The Rise and Decline of the Action for Scandalum Magnatum, 1497-1773" (1978) 22 A.J.L.H. 216.

31 Baker, 6 Oxford History of English Law (2003) p.788.

32 (1617) Cro. Jac. 422.

33 (1613) Cro. Jac. 323 
other early examples (albeit not bastardy cases) of actions based on such loss. Of more relevance so far as the development of the action for slander of title is concerned however is a line of reported ${ }^{37}$ cases where the damage suffered by the plaintiff as a result of the defendant's statement was loss of a transaction relating to the plaintiff's land. The line begins in 1583 with Banister $\mathrm{v}$ Banister, ${ }^{38}$ in which the plaintiff, the heir of land from his father, was successful in an action on the case brought as a result of the defendant's calling the plaintiff a bastard, on the basis that the accusation tended to his disherison of the land. Although there is no mention of the loss of a sale of the land in Coke's note of the case, it appears that this was shown by the plaintiff. ${ }^{39}$ The line continues with Vaughan $\mathrm{v}$ Ellis, ${ }^{40}$ in which the land in question was held under an entail. The plaintiff was the youngest of a number of sons, and had been offered a sum for his title to the land. As a result of being called a bastard by the defendant the sale fell through. In an action by the plaintiff the defendant relied on the fact that the plaintiff had no present title to the land. The court gave judgment for the plaintiff, on the basis that although he had no present title, there was the possibility that he might inherit the land.

In Vaughan v Ellis the plaintiff would inherit, if at all, by reason of the entail under which the land was held. Humphreys and Studfield's Case $e^{41}$ was one where the plaintiff's inheriting the land or not depended not on operation of law but on the decision of the plaintiff's father and brother. The plaintiff's complaint was that by reason of the accusation of bastardy the father and the brother intended to, and did in fact, give the land to someone other than the plaintiff. The action was successful, Banister v Banister and Vaughan v Ellis being relied on as precedents. The report of the case by Croke is of interest in that it records that the plaintiff would have been successful even if he had not been disinherited by the father and brother. Were that to have been the case, it is hard to see how the plaintiff could have succeeded unless an accusation of bastardy itself implied damage, or an action lay for the possibility of damage. Authority did exist that calling someone a bastard was itself sufficient to ground an action: in Elborow v Allen ${ }^{42}$ the court by a majority held that the words complained of ("Shall Elborow's wife sit above my wife? He is but a bastard.") were "in themselves scandalous and dangerous to cause his inheritance to be questioned", but the point was

34 (1614) 2 Bulst. 276; sub nom Sell v Fairee 1 Rolle 79.

35 (1599) Cro. Eliz. 787.

36 (1628) Litt. 193.

37 An earlier unreported case, Pulham v Pulham (1523), on the same issue is mentioned by Professors Baker and Helmholz: see Baker, 2 The Reports of Sir John Spelman (1978) 94 Selden Society p.241 n.2; Helmholz, op. cit., p.lxxi n.7; Baker, An Introduction to English Legal History (4th ed., 2002) p.440 n.2; Baker, 6 Oxford History of the Laws of England (2003) p.788.

38 (1583) noted in 4 Co. Rep. 17a.

39 See Elborrow v Allen (1622) Palm. 299. The other reports of the case do not mention the point.

40 (1608) Cro. Jac. 213.

41 (1637) Godb. 451; sub nom Humfreys v Stotville Jones W. 388; sub nom Humfreys v Stanfeild Cro. Car. 469.

42 (1622) Cro. Jac. 642; sub nom Elborough v Allen 2 Rolle 249; sub nom Elborrow v Allen Palm. 299. 
clearly a questionable one, the court a few years later in Law v Harwood ${ }^{43}$ distinguishing words such as "thief" and "bankrupt" which implied loss, from words such as "whore" and "bastard" where the court considered damage had to be shown. The alternative argument, that an action lay for the possibility of damage, divided the court some years later in Turner $\mathrm{v}$ Sterling. ${ }^{44}$ According to Ventris' report of the case, Wylde J. held the plaintiff entitled to succeed because the law gave an action "for but a possibility of damage, as an action for calling an heir apparent, bastard". It appears however from Freeman's report that that proposition was not accepted by Vaughan C.J..

The cases in which the plaintiff obtained redress in the common law courts for having been called a bastard are of interest not only in showing the importance attached at the time to a term which today is probably little more than a term of abuse. Fornication and adultery were spiritual offences punishable in the Ecclesiastical courts, rather than in the King's courts. ${ }^{45}$ In Davis v Gardiner ${ }^{46}$ it was argued that if an offence was punishable in the Ecclesiastical courts, the remedy for defamation consisting in the accusation of the offence was there also. That accusations of fornication or adultery were actionable in the Ecclesiastical courts is clear from a text published some years earlier. ${ }^{47}$ Whether or not cases in which the plaintiff brought an action in the King's courts as a result of being called a bastard involved a jurisdictional conflict between the Ecclesiastical courts and the King's courts, ${ }^{48}$ the more important point for present purposes is that the cases show the King's courts granting relief where statements made by the defendant caused damage to the plaintiff in the form of the loss of a transaction relating to the plaintiff's land, or the loss of an inheritance of land. If the plaintiff's ownership of land depended on his being the legitimate heir of his predecessor in title, an accusation of bastardy would clearly put the plaintiff's title in doubt. The action for slander of title bears a marked resemblance to such cases.

\section{Action for forgery of deeds}

Various possible origins for actions in the King's courts for words have been identified. ${ }^{49}$ One in particular is of interest so far as actions for slander of title are concerned. By the Forgery Act 1413 it was provided that landowners whose titles had been put in question by defendants who had forged deeds could bring actions for damages. The mischief recited in the

43 (1628) Cro. Car. 141; sub nom Harwood \& Lowe Palm. 529; sub nom Lowe v Harewood Jones W. 196.

44 (1671) 1 Freem. 15; 2 Ventr. 25. For proceedings in error against the decision see Sterling v Turner (1672) 1 Ventr. 206; sub nom Sterling \& Turnor 3 Keble 26; sub nom Starling v Turnor 3 Keble 32; sub nom Starling v Turner 2 Lev. 49.

45 Holdsworth, 1 History of English Law (1903) p.619; Davis v Gardiner (1593) 4 Co. Rep. 16b.

46 (1593) 4 Co. Rep. 16b.

47 Natura Brevium (1528 ed.) f.155, quoted in Baker \& Milsom, Sources of English Legal History (1986) p.625.

48 See Baker, 2 The Reports of Sir John Spelman (1978) 94 Selden Society p.241, n.2. For temporal and spiritual defamation see Baker, 6 Oxford History of the Laws of England (2003) p.788.

49 Helmholz, op. cit., p.lxviii. 
statute was the forgery and publication of such deeds causing the King's liege people "to be troubled and vexed and at all times abiding in doubt of their possessions and estate". Litigation between Lord Beauchamp and Sir Richard Croft at the end of the fifteenth century provides an interesting illustration of an action under the statute and an example of the scandalum magnatum action in the common law courts mentioned earlier. The litigation began with Sir Richard bringing an action against Lord Beauchamp pursuant to the statute, alleging that Lord Beauchamp had forged deeds. Lord Beauchamp's response was to issue a writ against Sir Richard on the ground that the allegation of forgery was actionable as a slander. ${ }^{50}$ The outcome of the litigation is not of importance to the present discussion. What is of relevance is that it appears that as time went by references to the Forgery Act came to be omitted from declarations in actions brought under it, plaintiffs merely asserting their good title to their land. ${ }^{51}$ The development of an action for slander of title against such a background is understandable. The Forgery Act had established an action for damage caused to the plaintiff by the defendant's forging deeds and thereby putting the plaintiff's title in doubt: the action for slander of title extended the circumstances in which an owner of land would be granted relief beyond cases of forgery into cases where the defendant's words had similar consequences.

\section{Emergence of the Tort}

Instances in the Plea Rolls involving actions for slander of title from early in the sixteenth century have been identified by Professor Baker. ${ }^{52}$ The first reported cases are decisions of the courts from later in the century. Some are cases where the words spoken can only relate to the plaintiff's title to land, but in some cases the words complained of can be seen either as relating to the plaintiff's title, or to the plaintiff himself. ${ }^{53}$ The bastardy cases are the clearest example, but not the only one. The words in Williams and Linford's Case $^{54}$ that "Williams is worth nothing, and do you think the manor of D. is his? It is but a compact between his brother Thomas and him" can be seen either as defaming the plaintiff by impugning his solvency, or as a slander of his title to the manor referred to. The case appears to be dealt with as one of slander of title, Wray J. saying that it mattered not whether the words spoken were to a potential purchaser of the land or to a third party, "for in both cases the title of the plaintiff is slandered, so as he cannot make sale of his lands". The same possibility that the words spoken would be actionable because they relate to the plaintiff's person, or alternatively because they slander the plaintiff's title can be seen in the later case of Bois $\mathrm{v}$ Bois,,${ }^{55}$ where the words complained of were that the plaintiff was a whore. An allegation of immorality against a woman had led to a successful action in Davis $\mathrm{v}$

50 Lord Beauchamp v Croft (1497) Keilway 26; Dyer 285a; also reported in Baker, 1 The Reports of John Caryll (1999) 115 Selden Society p.349.

51 Helmholz, op. cit., p.lxxi.

52 Baker, 6 Oxford History of English Law (2003) p.788.

53 The possibility that words spoken may give a cause of action in defamation or alternatively for slander of title exists today: see Gatley, para.20.3. For possible advantages in framing the complaint as one of slander of title, see Price \& Duodu, op. cit., para.6.02.

54 (1588) 2 Leon. 111; 3 Leon. 177.

55 (1664) 1 Lev. 134; 1 Keble 731 \& 758; sub nom Boys v Boys 1 Sid. 214. 
Gardiner $^{56}$ in 1593, but the interest for present purposes is that in Bois v Bois the plaintiff held land while she was sole and chaste. An allegation of immorality therefore not only defamed the plaintiff, it put her at risk of losing her land. ${ }^{57}$

The reported cases on slander of title begin with an anonymous case in 1564 reported by Dalison. ${ }^{58}$ This again was an allegation of bastardy, but this time not against the plaintiff. The action was brought following the defendant's statement that the plaintiff's father was a bastard. The report of the case, in which the plaintiff was successful, is interesting for a number of reasons. The court was split over the question whether the plaintiff could succeed if the words had related to the plaintiff rather than his father. As we have seen, later cases dealt with that issue. Secondly however, the court clearly thought that an action would lie in a case where the plaintiff suffered loss of his land because the defendant said the plaintiff's elder brother, being a bastard, was legitimate. An action in such circumstances can only be one of slander of title. Such an action took place a few years later, and is also reported by Dalison. In Booth $\mathrm{v}$ Trafford ${ }^{59}$ the plaintiff was the daughter of a settlor and had inherited land in default of any son of the settlor who would take a prior estate under the settlement. The plaintiff brought an action on the basis of a statement by the defendant that the settlor's wife had a son following her marriage with the settlor. The action failed however on the pleadings. Bliss v Stafford ${ }^{60}$ reported by Owen, appears to be the same case.

Johnson $\mathrm{v}$ Smith ${ }^{61}$ is another early case in which an action for slander of the plaintiff's title failed. The action was brought against an attorney on the basis of advice (that the land was burdened by a rentcharge) given by the latter to a prospective purchaser of the land, and as a result of which the sale had fallen through. Why the action was unsuccessful is not made clear in the report of the case ${ }^{62}$ but the case shows that the action had been clearly established by 1584 . The same can be seen from Mildmay's Case, ${ }^{63}$ which was widely reported, though not principally on the issue of slander of title.

56 (1593) 4 Co. Rep. 18a.

57 Such a situation had been envisaged in Davis v Gardiner and in Sell v Facy (1614) 2 Bulst. 76 (sub nom Sell v Fairee 1 Rolle 79) and was considered there to be a case in which an action would lie in the common law courts. It seems that in Bois $\mathrm{v}$ Bois the main concern of the court was the need for the plaintiff to prove special damage, and that the court distinguished the defendant's statement that the plaintiff was a whore from an earlier statement to like effect, but with the addition of a comment that the defendant intended to put the plaintiff out of her living. The case is complicated also because there was a single award of damages. The was adjourned and the outcome is not clear.

58 Anon (1564) Dal. 63.

59 (1573) Dal. 102.

60 (1573) Owen 37.

61 (1584) Moore 187.

${ }^{62}$ It seems the plaintiff was relying on what the defendant said as being hearsay. The only indication of the basis for rejecting the claim is a reference by Coke C.J. to an unreported case establishing that no action would lie for a statement amounting to a claim of title by the defendant. The decision is explicable on the ground that the defendant should have been free to give advice to his client.

63 (1584-5) 1 Co. Rep. 175a; Jenk. 247; sub nom Mildmay v Standish Cro. Eliz. 34; Moore 144. 
The most extensive of the reports of the case is by Coke, but it is primarily concerned with issues of land law arising in the case. A process of piecing together information from the various reports enables us however to understand the matters involved. The case appears to be the first reported instance of a successful claim based on slander of the plaintiff's title.

The action was brought by Anthony Mildmay and his wife Grace against Roger Standish for slander of title. The plaintiffs' declaration alleged that they were owners of land and had been in discussion with a third party for the grant of a lease of the land for 21 years. The defendant, knowing of such discussion, told the third party that one John Talbot and his wife Oliffe had an existing lease of the land for 1,000 years. In consequence of the statement, the third party declined to take a lease from the plaintiffs, who then brought the present action. The defendant's answer was essentially that his statement was true, a lease to Talbot and his wife having been made by the plaintiffs' predecessor in title. The problem was that the lease turned out to be invalid, for reasons which may be found in Coke's report, with the result that the defendant's statement was a slander of the plaintiff's title for which they were entitled to recover against the defendant. Sympathy for the defendant was clearly limited, Coke's report concluding "forasmuch as he hath taken upon him the knowledge of the law, and meddling with a matter which did not concern him, had published and declared, that Oliffe had a good estate for 1000 years, in slander of the title of Mildmay, and thereby prejudiced the plaintiff, ${ }^{64}$. . the judgment given for the plaintiff was affirmed in the writ of error; et ignorantia juris non excusat."

The statements which led to early actions for slander of title are as diverse as the more recent examples already noted. A statement that a third party had a lease of the plaintiff's land was the basis not only of the action in Mildmay's Case, but also in Pennyman $\mathrm{v}$ Rabanks ${ }^{65}$ and Earl of Northumberland $\mathrm{v}$ Byrt, ${ }^{66}$ though in the last of these the defendant sought to argue that the lease had been assigned to him, in order to defend the action by asserting a claim to the land himself. ${ }^{67}$ Statements in which the defendant was asserting a claim to the plaintiff's land were behind the actions in a number of cases. ${ }^{68}$ In other instances actions were brought for statements impugning the validity of a marriage of the plaintiff's wife, through whom the plaintiff derived title; ${ }^{69}$ for saying that the land should have devolved to someone other than the plaintiff; ${ }^{70}$ or that the defendant would rather buy the title of a named

64 According to the reports by Croke and Moore, the action was brought by Mildmay and his wife. Coke's report proceeds on the footing that the action was brought by Mildmay alone. His Book of Entries suggests that the action was by Mildmay and Grace: Coke, Book of Entries (1614) f.30.

65 (1595) Cro. Eliz. 427; sub nom Penniman v Rawbanks Moore 410.

66 (1607) Cro. Jac. 163.

67 Below, p.261.

68 Gerrard v Dickenson (1590) Cro. Eliz. 196; sub nom Gerard v Dickenson 4 Co. Rep. 18a ("I have a lease of the manor of Hely for ninety-nine years"); Lovett v Weller (1616) 1 Rolle 409 ("take heed how you buy it for it is mine") and Cane v Golding (1649) Style 169 \& 176 ("His right and title is naught, and I have a better title than he."); Cock v Heathcock (1677) 3 Keble 744 ("I have a surrender of the lands of B and intend to sue for the same, and that the plaintiff hath not title").

69 Bold v Bacon (1594) Cro. Eliz. 346.

70 Gresham v Grinley (1607) Yelv. 88. 
third party than the plaintiff's title; ${ }^{71}$ or more bluntly, that the plaintiff had no more right to the land than a mere stranger; ${ }^{72}$ that the plaintiff had no title to the land $;^{73}$ or had no power to sell it. ${ }^{74}$

\section{A separate cause of action}

That slander of the plaintiff's title to land had emerged as a separate cause of action from an action of defamation of the plaintiff is clear from two cases arising shortly after the Statute of Limitations 1623. The distinction is however apparent from cases before the Statute was enacted. Bold v Bacon ${ }^{75}$ is an early instance, Gawdy and Clench J.J. saying that the action there was "brought for slandering the plaintiff's title, and not his person". A later example is Sneade v Badley ${ }^{76}$ in which an action was brought as a result of the defendant's statement that the plaintiff had no more title to a named farm than a stranger. The case was determined on the sufficiency of the plaintiff's declaration in showing that the plaintiff has suffered damage. By a majority the court held that the declaration was insufficient for not stating that the plaintiff had been in negotiations for the sale of his land. ${ }^{77}$ The present relevance of the case is the distinction drawn by Croke J. and Coke C.J. between actions of slander of the plaintiff's title and actions of slander of the plaintiff himself. ${ }^{78}$ In the former but not the latter, Coke C.J. explained, it was necessary to aver that there had been negotiations for a sale which had fallen through. ${ }^{79}$

That a distinction had emerged between cases involving words which related to the plaintiff's person, and words which related to his title, is apparent also from Nelson v Staff. ${ }^{80}$ Here again the words complained of were that the plaintiff was a bastard. The action was brought on the ground that the

71 Crush v Crush (1605) Yelv. 80

72 Sneade v Badley (1616) 3 Bulst. 75; sub nom Smead v Badley Cro. Jac. 397; sub nom Swead v Badley 1 Rolle 409.

73 Marvin v Maynard (1595) Cro. Eliz. 419; Law v Harwood (1628) Cro. Car. 140; sub nom Harwood \& Lowe Palm. 529; sub nom Lowe v Harewood Jones W. 196.

74 Manning v Avery (1673) 1 Freem. 274; 3 Keble 153.

75 (1594) Cro. Eliz. 346.

76 (1616) 3 Bulst. 75; sub nom Smead v Badley Cro. Jac. 397; sub nom Swead v Badley 1 Rolle 409.

77 Below, p.258.

78 Bulstrode's report of the case records Croke J. saying that "[t]here will be a difference, where one doth slander and disable the person of another, as where one being an heir, the other saith, that he is not an heir, but a bastard, an action upon the case well lieth for this; . . . here in this case the slander is to the title of the land; and this is no slander without damage; . .." Rolle's report is to similar effect: "Crooke action gist si home dit que auter que est un heire est un bastard quod fuit concessum per Dod[deridge J] pur ceo que vae al person, mais auterment est en nostre case ..."

79 "For to call one a thief, or a villein regardant, \&c. This is good cause of an action upon the case; without any averrment here in this case, the plaintiff being seised of a mannor: another saith unto him, you have no right unto this. I do somewhat doubt of these words, whether actionable. . . . This difference is to be observed, that an action upon the case for words, which do tend to the slandering of the person of one, may be without any averment; but not so where the words are for slandering of the title..."

80 (1617) Cro. Jac. 422. 
defendant's statement had led to the plaintiff losing a marriage for which he was in negotiations prior to the statement being made. After judgment for the plaintiff the defendant brought a writ of error. The errors alleged included the omission of the plaintiff to show he was heir to the owner of the land. The judgment was affirmed however on the ground that the action was not one for slander of title, in which the court considered such an averment might be needed, but was for the loss of the marriage, and was based on defamation of the plaintiff.

The Statute of Limitations 1623 made the distinction between actions for slander of title and actions for slander of the plaintiff personally important for two reasons. By the Statute it was provided that an action on the case for words was subject to a limitation period of two years, ${ }^{81}$ and that in cases where an award was made in such actions which was less than 40 shillings, the costs recoverable by the plaintiff would be limited to amount of damages. $^{82}$ In Law v Harwood ${ }^{83}$ the court by a majority held that the provisions of the Statute both as to limitation and as to costs did not apply to an action for slander of title. ${ }^{84}$

\section{Elements of the Tort}

Two aspects of the action for slander of title in particular concerned the courts in the early days. One concerned the proof of damage which the plaintiff needed to establish in order to succeed; the other concerned the defendant's ability to assert a claim of his own to the land in question without running the risk of an action against him on account of such assertion. In addition to these matters however, it appears from the early cases that it was not a requirement that the plaintiff should show in his declaration what estate he held in the land, ${ }^{85}$ and that the defendant would not escape liability by showing he made the statement to someone other than a would-be purchaser or lessee. ${ }^{86}$

\section{The need to show a colloquium}

The basis on which the common law courts took cognisance of complaints based on statements made concerning the plaintiff was, as we have seen, that the plaintiff had suffered damage as a consequence of the statement. In actions for slander of title, the early reported cases invariably show such damage being established in the form of the loss of a transaction relating to the plaintiff's land, for which he had been in negotiation, and which had fallen through as a result of the slander of the plaintiff's title by the defendant. In Johnson v Smith, ${ }^{87}$ the plaintiff's declaration stated that the plaintiff was seised of certain land from his father and was in communication with $B$ to sell it to him, but that as a result of advice given by the defendant (an attorney) B refused to buy the land, as did all others, in consequence of

81 S.3.

82 S.6.

83 (1628) Cro. Car. 140; sub nom Harwood \& Lowe Palm. 529; sub nom Lowe v Harewood Jones W. 196.

${ }^{84}$ See also Nurse v Pounford (1629) Hetley 161.

85 Marvin v Maynard (1595) Cro. Eliz. 419.

86 Williams and Linford's Case (1588) 2 Leon. 111; 3 Leon. 177; above, p. 253.

87 (1584) Moore 187. 
which the plaintiff suffered damage in the loss of the price and the value of the land. Similarly, in Lovett $\mathrm{v}$ Weller, ${ }^{88}$ the declaration stated that the plaintiff was seised of land and in discussion for the sale of it to a third party, when the defendant spoke the words complained of, by which the plaintiff lost his bargain. Negotiations for a sale which fell though were likewise the background to the complaint in Pennyman $\mathrm{v}$ Rabanks. ${ }^{89}$ In Mildmay's Case, ${ }^{90}$ Gerard $\mathrm{v}$ Dickenson ${ }^{91}$ and Earl of Northumberland $\mathrm{v}$ Byrt, ${ }^{92}$ the declarations complained that the slander had resulted in the loss of a lease by the plaintiff for which he had been in discussion prior to the defendant's statement. In Williams and Linford's Case, ${ }^{93}$ the complaint was that the slander had resulted in the loss of an exchange of land. The requirement for the plaintiff to show loss of a transaction for which he had been in discussion was made plain in Bold $\mathrm{v}$ Bacon, ${ }^{94}$ Fenner J. saying " $[\mathrm{t}]$ his action [slander of title] lieth not but by reason of the prejudice in the sale; and this appeareth not..."

The requirement to show discussions which had fallen though as a result of the defendant's statement was strictly adhered to. A declaration which stated merely that the plaintiff intended to sell the land or to make a lease would result in the action failing, ${ }^{95}$ the reason being that such a declaration did not show that the plaintiff had suffered damage. ${ }^{96}$ In Sneade v Badley, ${ }^{97}$ the court was divided on the point. The plaintiff's declaration stated that the plaintiff had a purpose and intent to convey part of his land to his son for his advancement and to lease another part of the land, and that as a result of the defendant's slander of the plaintiff's title, the plaintiff was unable to make any lease or other assurance for his son. Houghton J. thought that the declaration was sufficient to allow the plaintiff to succeed, on the basis that the slander would dissuade others from buying the land from the plaintiff. Dodderidge and Croke J.J. held it was not, as the declaration did not show damage had been suffered by the plaintiff. The basis of Dodderidge J.'s decision was that notwithstanding the defendant's statement the plaintiff was

88 (1616) 1 Rolle 244.

89 (1595) Cro. Eliz. 427; sub nom Penniman v Rawbanks Moore 410.

90 (1584-5) 1 Co. Rep. 175a; Jenk. 247; sub nom Mildmay v Standish Cro. Eliz. 34 Moore 144

91 (1590) 4 Co. Rep. 18a; sub nom Gerrard v Dickenson Cro. Eliz. 196.

92 (1607) Cro. Jac. 163

93 (1588) 2 Leon. 111; 3 Leon. 177.

94 (1594) Cro. Eliz. 346.

95 See Sell v Facy (1614) 2 Bulst. 276; sub nom Sell v Fairee 1 Rolle 79, where the principle was applied in a case where the complaint was that the plaintiff had lost a marriage, Coke C.J. saying that in an action for slander of title a declaration that "quod intendebat, \& conatus fuit, for to sell [the plaintiff's land], this is not good, but he ought to lay precisely, that he was in speech and communication for the sale of this ..."

96 See Gresham v Grinley (1607) Yelv. 88 where the declaration showed that the plaintiff had an intention to make a jointure to his wife and to transfer parts of his land to his children. The action failed, one reason being "[b]ecause it does not appear by any thing in the declaration that the plaintiff is damnified, viz, that he was about to sell it, or had enter'd into a bond to make a jointure to his wife, which by reason of such words would not be accepted".

97 (1616) 3 Bulst. 75; sub nom Smead v Badley Cro. Jac. 213; sub nom Swead v Badley 1 Rolle 244. 
still able to settle the lands on the son. Croke J.'s decision was based on the proposition that damage could not be shown unless the plaintiff's declaration stated the plaintiff had been in negotiations for the sale or the land, and that these had fallen though as a result of the defendant's statement. The case was adjourned, and when it came before the court again, judgment was given for the defendant, Coke C.J. saying that it was necessary that the defendant's words should have hindered the plaintiff in the sale or leasing of the land, and that this had both to be expressed in the declaration and proved on the evidence..$^{98}$

Elborow v Allen ${ }^{99}$ also resulted the court being divided on the question whether the plaintiff needed to state in his declaration he had been in discussion for a sale or lease of his land. The basis of the case was that the plaintiff had been called a bastard by the defendant. By a majority (Ley C.J., Chamberlaine and Houghton J.J.; Dodderidge J. dissenting) the court held that the plaintiff could succeed notwithstanding the absence of any averment that there had been discussions for a sale or lease and that these had fallen through as a result of the defendant's statement. If the case is one where it was the person of the plaintiff which is slandered, then there was authority in Sneade v Badley for the proposition that no such averment was necessary. It seems however from the reports by Palmer and Rolle that the court proceeded on the basis that it was protecting the plaintiff's title. ${ }^{100}$ If that is the case, it is hard, on the basis of the earlier authorities, to disagree with the view of Dodderidge J. that the plaintiff needed to show discussions for a transaction, which had fallen through as a result of the statement made by the defendant. ${ }^{101}$

Later cases confirm the requirement that in cases of slander of title the plaintiff had to show discussions for a sale or lease which had fallen through as a result of the slander. Law v Harwood ${ }^{102}$ has already been noted. In Tasburgh v Day, ${ }^{103}$ the assertion that the plaintiff intended to sell an advowson in order to pay his debts, and that by reason of the defendant's

98 Speaking of the plaintiff's declaration, Coke C.J. explained: "here it is said, habens propositum \& intentionem, this is not good; but if he had said, habens colloquium \& propositum, this had been good cause of action".

99 (1622) Cro. Jac. 642; sub nom Elborrow v Allen Palm. 299; sub nom Elborough v Allen 2 Rolle 248.

100 In Palmer's report the basis of the decision of the majority is that "quia ceux parols come sont layd en le declaration, sont actionable; quia le parties est scandal en son title, $\&$ inheritance, p cest note $\&$ imputation de bastardy; car cest Court doet ptect son title". Rolle reports Chamberlaine J. as saying that "si home que avoit terre per discent soit called bastard ceo est tout come si fuit dit il avoit null title a ses terres, though there be no communication de son title, \& vous naves null case in le ley que dit, que pur calling un bastard generalment, que action ne voilt giser jeo die, que si home que ad terres per purchase soit call un bastard, que el poet aver action, pur ceo que sil nad heire de son corps son terre escheater".

101 The judgment of Dodderidge J. proceeds from the starting point that an allegation of bastardy was a matter for the Ecclesiastical courts, and that to ground an action in the common law courts it was necessary to show damage for which an award could be made, neither element of which had been established by the plaintiff.

102 (1628) Cro. Car. 140; sub nom Harwood \& Lowe Palm. 529; sub nom Lowe v Harewood Jones W 196.

103 (1618) Cro. Jac. 484. 
statement the plaintiff was hindered in the sale, was held to be insufficient, the court giving judgment for the defendant whose argument that the declaration did not show any communication to sell it which had been hindered by the defendant's statement appears to have been accepted. Cane v Golding ${ }^{104}$ and Manning $\mathrm{v}$ Avery ${ }^{105}$ are to like effect.

\section{Claim of title by defendant}

Just as it became established from an early date that the plaintiff needed to show that he had been in discussions for the sale or a lease of his land, so it is also clear from the earliest reported cases that the defendant would not be liable in an action for slander of title if the defendant claimed title in himself to the land, even though such claim were untrue. In Banister v Banister, ${ }^{106}$ the report records the court having resolved that if the defendant pretended the plaintiff were a bastard, and that he (i.e. the defendant) was the next heir, no action would lie. In Johnson v Smith, ${ }^{107}$ Coke C.J. refers to an earlier case, apparently unreported, for the proposition that no action would lie where the defendant claimed title to the land. The proposition is applied in a number of cases. In Lovett $\mathrm{v}$ Weller, ${ }^{108}$ the plaintiff failed in an action brought as a result of the defendant's statement to a third party negotiating to buy the plaintiff's land "take heed how you buy it for it is mine". Likewise in Cock v Heathcock, ${ }^{109}$ the plaintiff failed in an action founded on the words "I have a surrender of the lands of B. and intend to sue for the same, and that the plaintiff hath no title". ${ }^{110}$ The reason for the proposition is that were the position otherwise, no claim could be put forward without the risk of an action against the claimant. ${ }^{111}$

The rule that an action for slander of title would not succeed where a claim of title was the basis of the action did not assist a defendant unless the claim were that the defendant himself had title. If the defendant's statement was that a third party had title to the land, then the defendant would be liable in an action for slander of title, assuming the defendant's statement were untrue. That had been the reason why the defendant in Mildmay's Case was liable, the defendant's statement being that a lease of the land had been made to a third party. ${ }^{112}$ This distinction between immunity from action where the defendant claimed title himself, and liability where the assertion was that title existed in a third party, led to cases where the statement was apparently an assertion that a third party had title (in which case the defendant was going to be liable) but where the defendant sought to show that the title claimed was in fact his own (so defeating the plaintiff's action). In Pennyman v Rabanks, ${ }^{113}$ an action was brought for the words "I know one

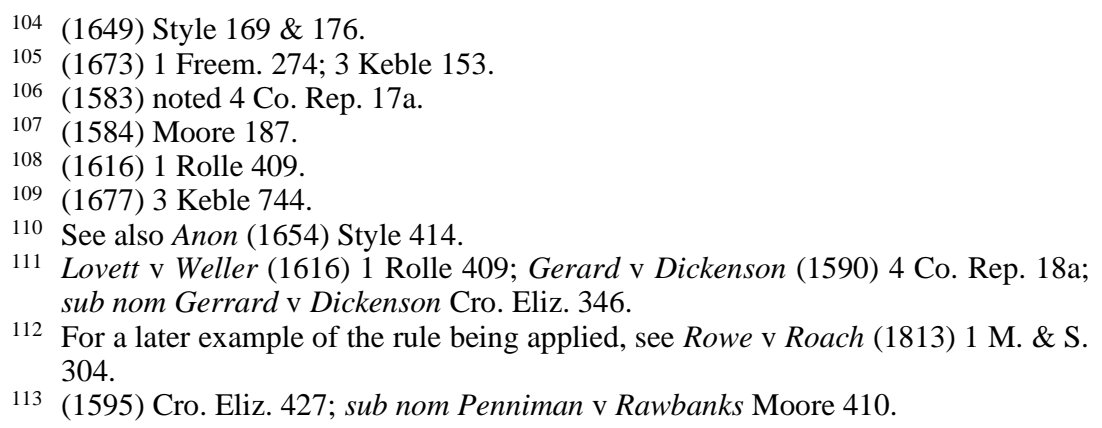


that hath two leases of [the plaintiff's] land, who will not part with them at any reasonable rate". In a motion to arrest judgment obtained by the plaintiff, the defendant argued that the statements referred to leases made to himself. The court was unanimously of opinion that no action lay against a defendant who claimed title himself, even though such claim were false. Moore's report of the case states however the court divided on the point whether the defendant could succeed on the basis that the words referred to leases to himself, Popham J. taking the view that the defendant could not succeed on this point, but Gawdy and Fenner J.J. of opinion that he could. Croke's report shows that the judgment obtained by the plaintiff was affirmed, but the point under discussion is left unclear. A similar point arose in Earl of Northumberland $\mathrm{v}$ Byrt, ${ }^{114}$ where the defendant had said that the plaintiff's predecessor had made a lease to a third party. The defendant sought to argue that the third party had later assigned the lease to the defendant, so that the defendant had spoken in maintenance of his own title. The court rejected the argument, as the words imported that the defendant had spoken them "to countenance the title and interest of a stranger, which is not lawful" and that the defendant could not subsequently rely on the assignment to him to avoid liability.

A claim of title based on a lease to someone other than the defendant was the basis of the action in the more difficult case of Gerard v Dickenson. ${ }^{115}$ There is a statement by Richardson J. in Nurse v Pounford"116 that "they had alwaies conceived Sir Gilbert Gerrards case not to be law", but the criticism can only refer to the construction put by Wray C.J. on the words spoken by the defendant in the case, or to the decision being based on the ground of the defendant's knowledge, for the case does not depart from the general principle that a defendant asserting a claim to title in himself is not liable in an action for slander of title. The action was brought as a result of the defendant's statement that she had a lease of the plaintiff's land. The lease was one which had been made to her husband, but which appears to have been forged. The court held that the defendant was liable to the plaintiff in an action for slander of the plaintiff's title. In resolving that no action would lie if the defendant had affirmed and published that the plaintiff had no title, but that the defendant had title herself, even though such claim were false, the court was reasserting the principle already established; and accordingly in holding, on this ground, that the defendant was not liable as a result of her statement, the court's decision is unobjectionable. The court went on however to hold the defendant liable on grounds based on the defendant's knowledge that the lease was a forgery. ${ }^{117}$ For present purposes interest lies in Croke's report of the case, from which it appears that Wray C.J. considered the words "I have a lease" were not to be construed as meaning that the defendant claimed to be entitled to the term created by the lease, but meant merely that she had a deed (in favour of her husband) in her possession. The Chief Justice went on to say that had the defendant said that she had an interest or term for ninety-nine years, and entitled herself to it, she

114 (1608) Cro. Jac. 165.

115 (1590) 4 Co. Rep. 18a; sub nom Gerrard v Dickenson Cro. Eliz. 196.

116 (1629) Hetley 161.

117 On this point the decision was considered "a particularly hard one" in Wren v Weild (1869) L.R. 4 Q.B. 730. 
would not have been liable. There is nothing objectionable in that statement, but the initial construction of the defendant's words seems questionable, and was not shared by Gawdy J., who took the view that they amounted to a claim to the leasehold term.

Finally, one of the last of the cases from the seventeenth century raises a matter which would come to be of more concern later. The report of Goulding v Herring ${ }^{118}$ records that it was agreed that though the defendant claimed the title, "yet being malitiose found by verdict the action lieth, but if upon the evidence any probable cause appeared of claim, it ought not to be found malitiose". The question of malice had featured very little in the early cases, but would become the main concern for the courts in the nineteenth century.

\section{Slander of Title Revived}

The early reported cases on slander of title span the period 1564 to 1677 . Thereafter the tort disappears from the reports, before resurfacing in Hargrave $\mathrm{v}$ Le Breton almost another century later. When it does, the main concern of the courts appears to be the need for the defendant's statement to have been made maliciously. ${ }^{119}$ Although there are references in some of the cases from the earlier period to malice, ${ }^{120}$ none of those cases appear to have turned on the issue, and it may be that the assertion that the defendant's statement was falso et malitiose was simply the standard form for pleading. ${ }^{121}$ Holdsworth ${ }^{122}$ explains that originally all that was meant by such allegation in actions on the case for words was that the words were spoken without just cause or excuse, but that use of the formula led to the belief that malice was an essential element. That belief was later laid to rest so far as actions for defamation were concerned, but that did not take place with actions for slander of title. Indeed quite the reverse occurred, the courts emphasising the need for the plaintiff in such actions to prove the words were spoken maliciously. ${ }^{123}$ This need for the plaintiff to prove malice is one

118 (1673) 3 Keble 141.

119 For the history of malice in defamation actions see Holdsworth, "Defamation in the sixteenth and seventeenth centuries" (1924) 40 L.Q.R. 302 \& 397; (1925) 41 L.Q.R. 13, p.24; Holdsworth, 8 History of English Law (1925) p.371. For the history of malice in actions for slander of title see Newark, "Malice in actions on the case for words" (1944) 60 L.Q.R. 366.

120 See Mildmay v Standish (1584) Moore 145 (“le def. ad malicousmt publish ...”); Elborow v Allen (1622) Cro. Jac. 642 ("although the plaintiff saith he was scandalized in his estate, and that [the words] were spoken maliciously, ...”); Cane v Golding (1649) Style $169 \& 176$ ("the saying that the words were spoken falso \& malitiose"); Goulding v Herring (1673) 2 Keble 141.

121 See Newark, op. cit., p.370, referring to Elborow v Allen (1622) Cro. Jac. 642 where the allegation in the declaration of malice was said to be "but the clerk's drawing and inserting". Cp Shepherd v Wakeman (1662) 1 Sid. 79 (action for defamation: "le incerting de falso \& malitiose in le declaration nest que formall ...").

122 Holdsworth, "Defamation in the sixteenth and seventeenth centuries" (1924) 40 L.Q.R. 302 \& 397; (1925) 41 L.Q.R. 13, p.24; Holdsworth, 8 History of English Law (1925) p.371.

123 See Hargrave v Le Breton (1769) 4 Burr. 2422; Smith v Spooner (1810) 3 Taunt. 246; Pitt v Donovan (1813) 1 M. \& S. 638; Pater v Baker (1847) 3 C.B. 831. 
of the features which distinguishes actions for slander of title from actions for defamation. In the latter, malice is relevant in certain instances, notably in defeating a defence based on qualified privilege, but otherwise the onus on the plaintiff does not require him to state that the defendant has spoken maliciously. ${ }^{124}$ Whether the courts were right in taking the view that a plaintiff in an action for slander of title must prove malice has been disputed, Professor Newark arguing that the true position ought to be that a plaintiff should be required to prove only that the words were spoken with intent to disparage, but that if the defendant raises a claim of title in himself, then the plaintiff must show the defendant spoke maliciously. ${ }^{125}$ The situation is, in other words, no different from an action for defamation in which the defendant raises a defence of qualified privilege. It seems from the authorities up until the late eighteenth century that such argument is compelling. Despite that however, it is likely the requirement that the plaintiff must discharge the onus of showing malice in cases of slander of title is now too long established to be overturned.

If the revival of the action led to an inflexible rule that the plaintiff prove malice, it led also to a less rigid view of the damage the plaintiff needed to establish. Early cases had proceeded on the basis that the plaintiff needed to show discussions for the sale or lease of the plaintiff's land, which discussions had fallen through as a result of the defendant's statement. In Malachy v Soper, ${ }^{126}$ Tindal C.J. was prepared to admit that these might be instances only, and that there might be other cases in which damage might be equally apparent without such allegation. The only support from the early authorities for the view that the need to show loss of a transaction is only an example of the damage which the plaintiff needs to establish is Law v Harwood, ${ }^{127}$ in which one error assigned by the defendant to the judgment obtained by the plaintiff was that the plaintiff's declaration was bad for not showing damage "as that he was bargaining for the inheritance with any or for a lease or any other special prejudice" (emphasis supplied). Apart from Law v Harwood, all the other cases proceed on the allegation of loss of a transaction.

The need for the plaintiff to show special damage has, as we have seen, been abolished in cases to which section 3 of the Defamation Act (NI) 1955 applies. In cases not provided for under the statute, e.g. where the defendant's statement has been spoken rather than written, the plaintiff will have to show that by reason of the defendant's statement the plaintiff has suffered damage. Whether the old cases in which the tort of slander of title evolved, almost all of which proceed on the basis that the plaintiff must show

124 Bromage v Prosser (1825) 4 B. \& C. 247, following Mercer v Sparks (1587) Noy 35; Owen 51; sub nom Mercer's Case Jenk. 268, and Anon (1652) Style 392. In the last mentioned, Rolle C.J. explains that "in an endictment, a thing must be expressed to be done falso et malitiose, because that is the usual form, but in a declaration those words are not necessary." See further Holdsworth, "Defamation in the sixteenth and seventeenth centuries" (1924) 40 L.Q.R. 302 \& 397; (1925) 41 L.Q.R. 13, p.26.

125 Newark, op. cit., p.376.

126 (1836) 3 Bing. (N.C.) 371.

127 (1628) Cro. Car. 140; sub nom Harwood \& Lowe Palm. 529; sub nom Lowe v Harewood Jones W. 196. 
negotiations for a sale or lease of his land which have fallen thought as a result of the defendant's statement, will be followed, or whether the courts sill prefer the more liberal approach to damage voiced in Malachy v Soper, is a moot point. It is thought unlikely that the more restrictive view of the old cases would appeal to the courts today.

\section{Conclusion}

In treating slander of title nowadays as an instance of a wider generic tort of malicious falsehood, attention has become focussed on the requirement that the plaintiff show that the defendant's statement was made maliciously. ${ }^{128}$ The early reported cases show this was not the concern of the judges who were called on to determine actions in which the plaintiff's complaint was that his title had been put in question by words spoken by the defendant. The action on the case for words had come into existence before the first reported cases were determined, and had separated into two forms, actions for defamation and actions for slander of title. In both forms, the principal concern of the courts was that damage had been caused as a result of the defendant's statement. In denying relief to plaintiffs where the defendant had claimed a title himself, the courts were seeking to ensure that those believing they had a right in or claim to the plaintiff's land could assert such right or claim without the risk of an action against them. The allegation that the defendant had acted falso et malitiose seems to have been no more than the standard form in which actions on the case for words, whether for defamation of the plaintiff or for slander of his title, were pleaded. Not long before it was established in Bromage v Prosser ${ }^{129}$ that the plaintiff need not allege malice in actions for defamation, Lawrence J. had said of actions for slander of title that malice was the gist of the action. ${ }^{130}$ The same statement had however been made in connection with actions for defamation, ${ }^{131}$ and it might have been expected that the view in Bromage $\mathrm{v}$ Prosser could have been applied to cases on slander of title. That it was not may be attributable to the view, already noted, expressed not many years later in Malachy $\mathrm{v}$ Soper, that such an action is "not properly an action for words spoken, or libel written and published". Whether that be so or not, the need for the plaintiff to prove malice on the part of the defendant in actions for slander of title resulted in the development of the action in a direction of which the early reported cases give little indication.

128 For modern authorities on the meaning of "malice" see Clerk and Lindsell, para.23.11 ff; Gatley, para.20.7 ff.

129 (1825) 4 B. \& C. 247.

130 Smith v Spooner (1810) 3 Taunt. 246.

131 Smith v Richardson (1737) Willes 24. 